\title{
Cough-induced hemiparesis: an unusual manifestation of cord compression
}

\author{
Karim Mahawish
}

Older Person Rehabilitation Services, Rotorua Hospital, Rotorua, New Zealand

\section{Correspondence to} Dr Karim Mahawish, kmahawish@doctors.org.uk

Accepted 12 May 2016
CrossMark

To cite: Mahawish K. BMJ Case Rep Published online: [please include Day Month Year] doi:10.1136/bcr-2016215537

\section{DESCRIPTION}

A 67-year-old woman presented with a 1-year history of recurrent episodes of simultaneous left arm and leg weakness and numbness. Each episode would last a matter of seconds and was always precipitated by coughing or sneezing. She was asymptomatic between episodes. Physical examination demonstrated a normal cardiorespiratory assessment, while examination of the neurological system demonstrated normal tone, power and sensation with generalised brisk reflexes and equivocal plantars.

Cervical spine X-ray performed in extension (figure 1) demonstrated an enlarged predentate space (distance between the anterior surface of the dens and the posterior surface of the tubercle) at $\mathrm{C} 1$, measuring $7.3 \mathrm{~mm}$ (normal distance $\leq 3 \mathrm{~mm}$ ), and a narrowed spinal canal measuring an anteroposterior (AP) distance of $8.4 \mathrm{~mm}$ (normal AP size $\sim 17 \mathrm{~mm}$, relative stenosis defined as $10-13 \mathrm{~mm}$ and absolute stenosis $<10 \mathrm{~mm}$ ). These findings were in keeping with atlantoaxial instability. Cervical spine

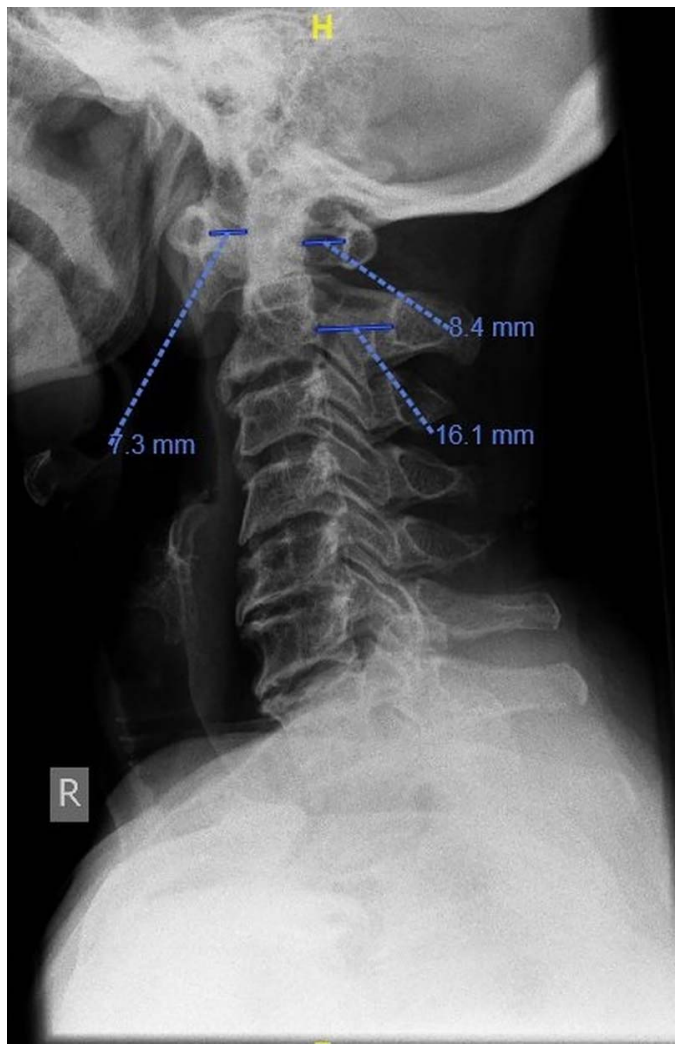

Figure 1 Lateral C-spine $\mathrm{X}$-ray in extension demonstrating an enlarged predentate space at $\mathrm{C1}$, measuring $7.3 \mathrm{~mm}$, and narrowed spinal canal measuring an anteroposterior distance of $8.4 \mathrm{~mm}$.

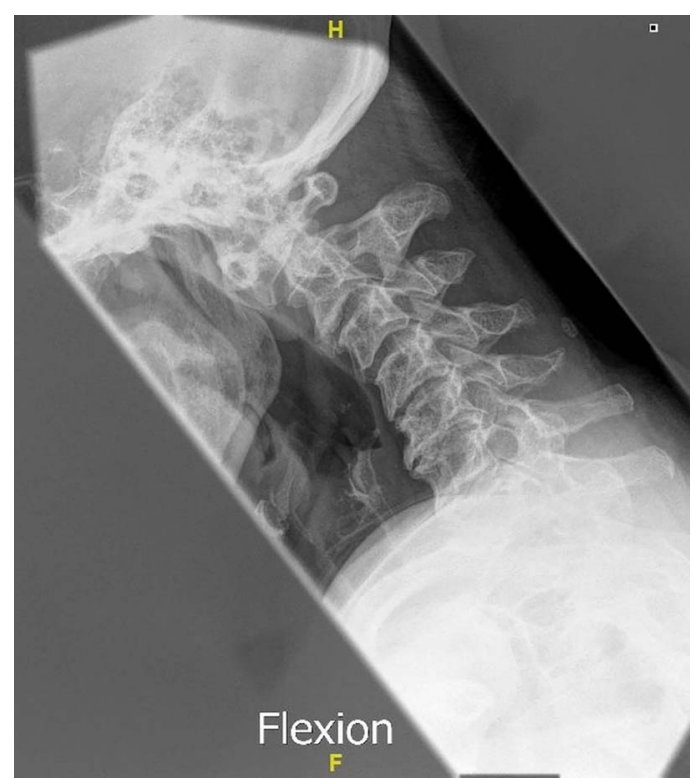

Figure 2 Lateral C-spine in flexion demonstrating further narrowing of the AP distance at $\mathrm{C} 1$. AP, anteroposterior.

X-ray in flexion demonstrated further narrowing of the spinal canal at C1 (figure 2). Sagittal MR T2 scan of the cervical spine demonstrated a posteriorly displaced peg with narrowing of the spinal canal at the $\mathrm{C} 1$ level to an AP dimension of $6 \mathrm{~mm}$ with likely compression of the cord (figure 3). MRI T2 axial slices through the cervical cord demonstrated left hemicord oedema (figure 4), accounting for the

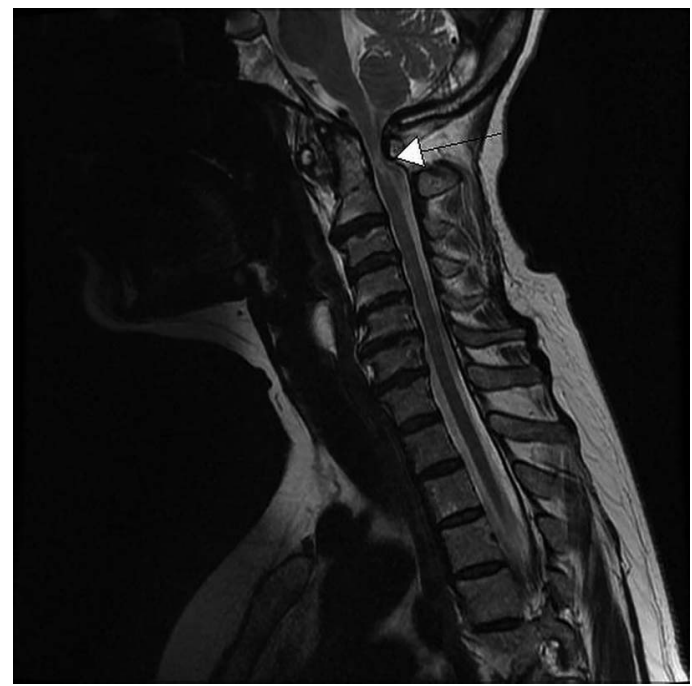

Figure 3 Sagittal MR T2 of the cervical spine demonstrating cord compression at the $\mathrm{C} 1$ level. 


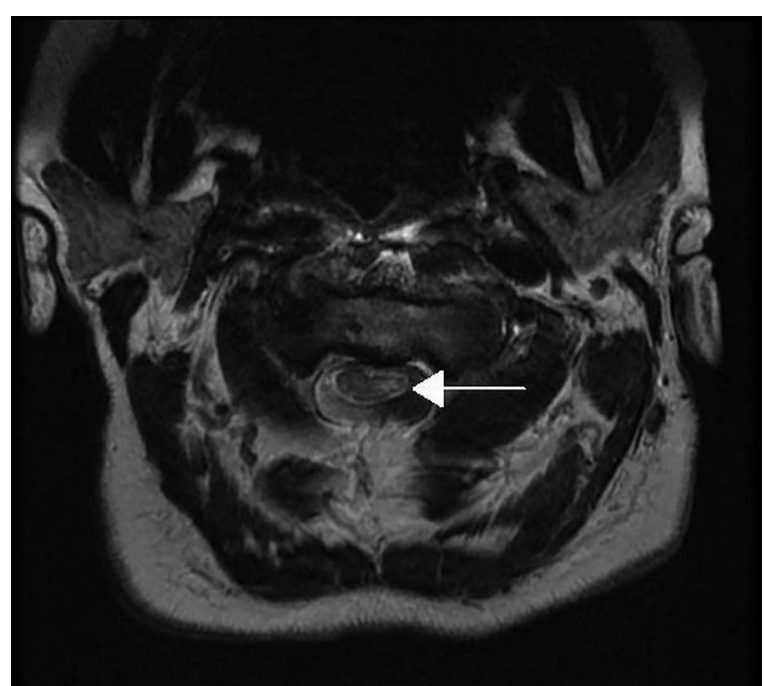

Figure 4 Axial MR T2 of the cervical spine demonstrating cord compression and left hemicord oedema.

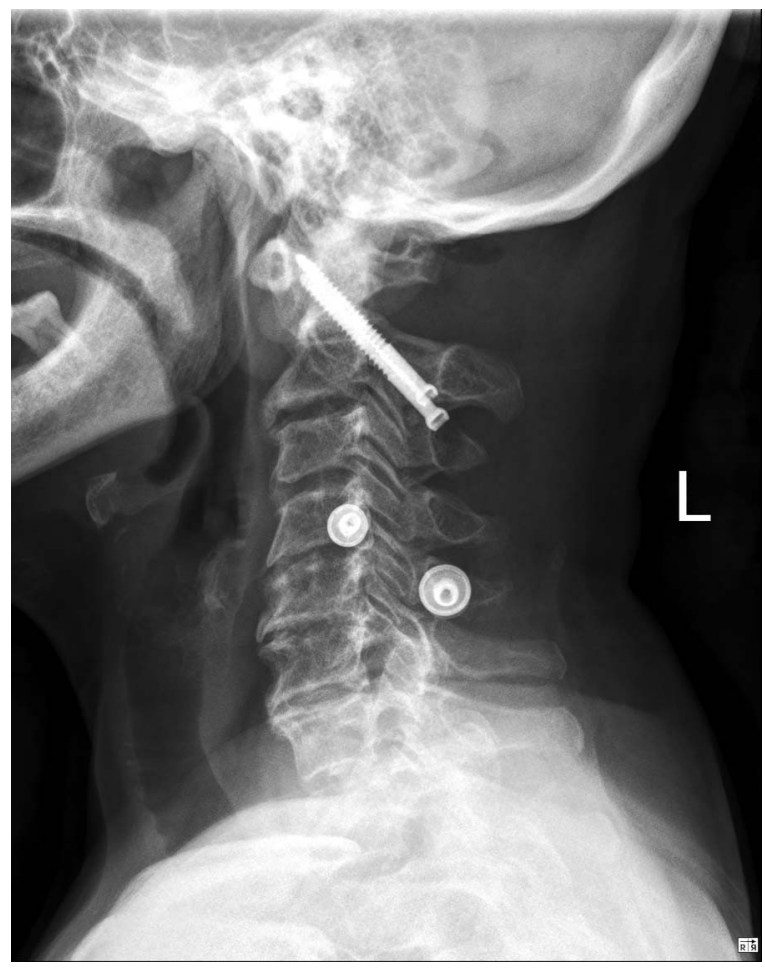

Figure 5 Lateral post-operative C-spine X-ray with fixation screws through $\mathrm{C} 1 / 2$. patient's predominantly left-sided symptoms. The patient underwent a C1/2 vertebral fusion (figure 5) and has remained asymptomatic since.

\section{Learning points}

- Transient ischaemic attacks or, less commonly, cerebral microbleeds, are more widely recognised causes of transient sudden onset focal neurological deficits. Other causes include focal seizures and metabolic derangements.

- Though uncommon, cord compression may present with transient unilateral signs and should be suspected when neurological symptoms are precipitated by sudden head movements.

- Patients presenting with recurrent focal neurological deficits should be admitted for urgent investigations as they are frequently associated with significant morbidity and mortality.

Competing interests None declared.

Patient consent Obtained.

Provenance and peer review Not commissioned; externally peer reviewed.

Copyright 2016 BMJ Publishing Group. All rights reserved. For permission to reuse any of this content visit

http://group.bmj.com/group/rights-licensing/permissions.

BMJ Case Report Fellows may re-use this article for personal use and teaching without any further permission.

Become a Fellow of BMJ Case Reports today and you can:

- Submit as many cases as you like

- Enjoy fast sympathetic peer review and rapid publication of accepted articles

- Access all the published articles

- Re-use any of the published material for personal use and teaching without further permission

For information on Institutional Fellowships contact consortiasales@bmjgroup.com

Visit casereports.bmj.com for more articles like this and to become a Fellow 